\title{
Extragonadal Germ Cell Tumor
}

National Cancer Institute

\section{Source}

National Cancer Institute. Extragonadal Germ Cell Tumor. NCI Thesaurus. Code C3918.

A germ cell tumor arising in an anatomic site other than the testis or ovary (e.g., central nervous system, lung, mediastinum, and retroperitoneum). 